\title{
MIR203A Pre-miRNA
}

National Cancer Institute

\section{Source}

National Cancer Institute. MIR203A Pre-miRNA. NCI Thesaurus. Code C82802.

MIR203A pre-miRNA (110 bases) is encoded by the human MIR203A gene. This

oligonucleotide may be involved in the regulation of epidermal gene expression. 